\title{
MODERN METHODS OF PIANO PERFORMANCE IN KLOSTER DRIAN'S COMPOSITIONS
}

\section{Hala Marouf AMER *}

Department of Music Education, Faculty of Specific Education, Tanta University, Egypt

\begin{abstract}
The twentieth century witnessed a great diversity in the styles and elements of musical composition in a way not seen in an era before, as a large number of composers discovered new sources of musical sounds, whose pioneers differed in thought, philosophy and creativity between returning to the old and the desire to reach everything new, and their trends contradicted. Between strict restrictions and absolute freedom, between the elements of art and the noise of nature, and between the interference of the human sense and the dominance of electronics.

Keywords

Modern, Methods, Piano, Performance, Kloster Drian's Compositions.
\end{abstract}

\section{Introduction:}

One of the advocates of these trends was a group called "Vanit Grade" who dominated the way some of them composed strict laws and absolute freedom, including Milton Batile and Pierre Bules And another group interested in experimentation called the Experimentalists, the most famous of whom was Charles Ives, Hanry Cowell and John Cage, who replaced performance techniques with newer techniques.

Among them was the French composer Clostre Adrienne (1921-), who was distinguished from other composers and compositions of her era by her different style of composition and method of notation, and is considered one of the French compositions known to them during the second half of the twentieth century towards the development of a snapshot The convergence of traditional and experimental in her works, seeking to produce sound colors of a different nature, which led to different performance requirements, and the performer had to broaden his musical horizons away from the established classical and romantic standards so that the performer could accept this type of music and achieve modern philosophy.

Therefore, the researcher chose the author Kloster Adrian to use modern techniques in addition to the traditional techniques of piano compositions in order to give new sound colors.

The research paper aims to identify the modern techniques of the twentieth century colloquial and the modern techniques that are included in Kloster Adrian's piano compositions.

First: the development of modern technologies, the word piano during the twentieth century:

Modern techniques for performing on a piano are divided into two main types:

1- Extended Piano Technique, meaning playing inside an instrument on the strings of the piano.

* Corresponding author: dean_spedu@sed.tanta.edu.eg 
2- Prepared Piano Techniques, which were invented by John Cage (1992-1912) the American, one of Cowell's students, and he was familiar with the stringed piano technique that his teacher used as he placed materials between the piano strings such as nails, metal joints and rubber tape ... Etc. to change the character of the instrument as in the piece Amores, and Charles Ives3 (1954-1874), the American musician, used to play the cluster a wooden and heavy tape to press the keys down without hitting, as in Sonata No. (2) titled Concord, Russian Lee Feeney. Ross Lee Finney (1906-1997) used the cluster method on white keys in a piece entitled White - Note Cluster.

Second: the author Cluster Adrian's piano compositions, which used the previous techniques:

Eight Variations (1976) Varitation Premier livre diesfois

Sonata (1980)

- Four introductions Interludes4

Four Italian variants Italiennes Varitiatin

Sonata

- A piece entitled (1981) Wares

- Paintings for Piano (1991) Lecture au Piano de Virginia Wolf

Some of the latest technologies used will be presented:

1. Performance on keyboard like cluster and muffled notes.

2. Performances in the piano such as clicking, striking, rubbing the strings with fingers and toes, and other things such as glysando on the strings and tremolo on the strings.

3. Performing on the piano with one hand and on the keyboard with the other, such as harmonies and muting or damping the strings.

4. Adding external materials such as nails, plastic, and rubber strip, which is called a piano prepared.

5. Diversity using wildcards.

6. Use sounds made on the frame.

7. Using external devices including adding human voices such as singing, speaking or whispering while playing the piano.

\section{Recommendations:}

1. The inclusion of Kloster Adrian's piano pieces within the curricula of graduate studies in the faculty due to the modern techniques they include.

2. The necessity for continuous reading, reading and research in the music of the twentieth century and the music of experimental compositions.

3. Interest in holding seminars to present the authors' work to clarify the method of performing 
modern technologies for researchers and students.

4. Providing music notes by twentieth century authors.

\section{References:}

- Nermin HAMDY, A PROPOSED PROGRAM TO TEACH CHILDREN FRENCH LANGUAGE BY PLAYING THE PIANO, International Journal of Education and Learning Research, Vol. 1, No. 1, 2018, pp. 1-9.

- Salwa Hassan Mohamed Mahmoud PASHA, ADVANTAGES OF BREATHING EXERCISES ON PIANO PERFORMANCE FOR BEGINNERS, International Journal of Education and Learning Research, Vol. 1, No. 1, 2018, pp. 10-17.

Received: July 15, 2018

Accepted: September 20, 2018 